\title{
PENGEMBANGAN BAHAN AJAR \\ METODE PEMBELAJARAN BAHASA DAN SASTRA INDONESIA \\ BERBASIS PEMBELAJARAN KOOPERATIF JIGSAW \\ UNTUK MENINGKATKAN PEMAHAMAN \\ DAN KEMAMPUAN APLIKATIF MAHASISWA
}

\author{
Gede Nurjaya \\ Jurusan Pendidikan Bahasa dan Sastra, Fakultas Bahasa dan Seni, \\ Universitas Pendidikan Ganesha, Singaraja, Indonesia
}

\begin{abstract}
Abstrak
Tujuan utama penelitian ini adalah menghasilkan bahan ajar Metode Pembelajaran Bahasa dan Sastra Indonesia yang mampu meningkatkan pemahaman dan kemampuan aplikatif mahasiswa. Untuk tujuan itu, rancangan penelitian yang digunakan adalah rancangan penelitian dan pengembangan (R\&D). Penelitian ini membutuhkan waktu dua tahun untuk menghasilkan produk yang siap pakai.

Pada tahun kedua ini adalah uji coba efektivitas penggunaan bahan ajar. Hasilnya adalah sebagai berikut ini. (1) Prestasi mahasiswa setelah diajarkan dengan menggunakan bahan ajar yang telah disusun berada pada kategori baik dengan rata-rata skor 79,42. Skor untuk pemahaman sebesar 81,17 dalam kategori baik, lebih tinggi dibandingkan skor kemampuan aplikatif yang sebesar 76,8 pada kategori baik juga. (2) Respon mahasiswa terhadap penggunaan bahan ajar dalam pembelajaran adalah positif dengan rata-rata 4,43 pada skala 5. (3) Kendalaa yang dihadapi oleh mahasiswa saat penggunaan bahan ajar tersebut dalam pembelajaran adalah kekurang waktu dan ada beberapa bagian bahan ajar yang sulit dipahami karena redaksinya.
\end{abstract}

Kata kunci: bahan ajar, prestasi, respon, kendala

\begin{abstract}
The study aimed at producing learning materials for the course of "Method of Indonesian language and arts" in order to be able to increase the students' comprehension and application. The research design used was resarch and development model (R\&D). The study needed some steps before producing a ready-to-use product.

In the second year of the reserach project, the study conducted an experiment to measure the efficacy of the product. The results of the experiment was as follows: a) Students achievement after being taught using the designed learning materials falls within the good category with $M=79.42$. The means of comprehension score is 81.17 which is categorised good. It is higher than the score of application which is 76.8 ; b) students response is very positif towards the use of designed learning materials as shown by means of score which is 4.43 at scale 5 . c) the only constraint faced by students in using the designed learning materials is the time allotment. Besides, some parts of the materials are difficult to understand, especially, their sentences.
\end{abstract}

Keywords: learning materials, achievement, response, constraint 


\section{PENDAHULUAN}

Mata kuliah Metode Pengajaran Bahasa dan Sastra Indonesia (MPBSI) adalah salah satu mata kuliah yang diharapkan dapat membentuk mahasiswa menjadi seorang guru Bahasa dan Sastra Indonesia. Dengan demikian, mata kuliah ini seharusnya membekali peserta didik berbagai konsep dan keterampilan mengajar yang dibutuhkan untuk menjadi seorang guru Bahasa dan Sastra Indonesia. Selain itu, mata kuliah ini seharusnyalah menjadi mata kuliah yang bersifat aplikatif bukan sekadar teoretis belaka. Hanya saja, untuk menjadikan mata kuliah ini sebagai bidang yang aplikatif tampaknya masih merupakan kendala yang perlu dipecahkan.

Dari pengalaman membimbing mahasiswa yang mengambil mata kuliah pengajaran mikro dan pada saat mereka praktik mengajar di sekolah, kentara sekali bahwa mahasiswa lebih banyak mengetahui hal inwal metode pengajaran bahasa secara verbalistis (teoretis). Pengetahuan mereka itupun kurang disertai pemahaman yang bersifat analitis apalagi praktis. Keadaan yang demikian ini menyebabkan mereka, umumnya, kurang memiliki keterampilan untuk mengaplikasikan konsep-konsep Metode Pengajaran Bahasa dan Sastra Indonesia dalam pembelajaran ketika mereka praktik mengajar. Pemahaman konsep mereka pun ternyata kurang memadai juga.

Keadaan demikian itu, tampaknya disebabkan oleh pembelajaran mata kuliah tersebut yang kurang memberikan kesempatan bagi para mahasiswa untuk, selain mampu memahami konsep metodelogi. juga mampu mengaplikasikannya dalam kegiatan pembelajaran.
Untuk menanggulangi permasalahan seperti itu, telah ditemukan model pembelajaran yang efektif yaitu pembelajaran kooperatif tipe jigsaw. Model ini ternyata mampu meningkatkan pemahaman teoretis dan kemampuan aplikatif mahasiswa dalam mata kuliah tersebut. Hal ini dimungkinkan karena model ini memberikan kesempatan kepada mahasiswa untuk memahami konsep metode PBSI tersebut secara berkelompok. Pemahaman secara berkelompok diharapkan mampu menjadi solusi pemecahan permasalahan yang muncul ketika mereka mempelajari konsep metode tersebut secara mandiri. Apalagi pada saat pemahaman konsep secara kelompok ini, mereka dibimbing oleh dosen pembimbingnya. Setelah terjadi pemahaman konsep, secara individu, mereka harus bertanggung jawab terhadap pemahamannya karena mereka akan menyampaikan pemahamannya kepada teman lain pada kelompok lain. Kegiatan menyajikan pemahaman kelompok oleh individu kepada teman dari kelompok lain ini mengharuskan mereka untuk memiliki pemahaman yang betul-betul baik agar kelompok lain juga memiliki pemahaman yang sama dengan yang dimiliki oleh kelompoknya sendiri.

Selain pemahaman yang baik terhadap konsep yang menjadi tugasnya, mahasiswa secara individu juga harus mempersiapkan teknik penyajian yang baik sehingga memudahkan teman dari kelompok lain memahami konsep yang disajikan. Pada tahap menyajikan konsep pada kelompok lain inilah berbagai startegi harus diterapkan dan berbagai perlengkapan untuk mengajar harus disiapkan. Tahap ini menjadi kunci 
penguasaan keterampilan mengaplikasikan berbagai konsep yang telah dikuasai.

Agar model pembelajaran dapat terlaksana dengan baik maka diperlukan perangkat pembelajaran lainnya seperti bahan ajar dan evaluasi yang relevan dengan model yang digunakan. Dengan pertimbangan bahwa model pembelajaran tidak dapat berdiri sendiri, tanpa perangkat pendukungnya, maka dilakukanlah penelitian pengembangan bahan ajar untuk mata kuliah Metode Pembelajaran Bahasa dan Sastra Indonesia.

Penelitian pengembangan bahan ajar Metode PBSI ini ditujukan untuk menghasilkan bahan ajar untuk mata kuliah Metode Pembelajaran Bahasa dan Sastra Indonesia yang berkualitas dengan berbasiskan pembelajaran kooperatif jigsaw untuk dapat meningkatkan pemahaman dan kemampuan aplikatif mahasiswa.

Untuk mencapai tujuan utama tersebut diperlukan tujuan khusus yang memerlukan dua tahap penelitian. Untuk tahun pertama, tujuan khusus ini adalah untuk menetapkan dan mendifinisikan syarat-syarat bahan ajar yang sesuai dengan kebutuhan kurikulum dan kebutuhan mahasiswa, menemukan prototype bahan ajar yang dibutuhkan, dan menetapkan tingkat validitas bahan ajar melalui validasi. Tujuan tahun kedua adalah untuk mengetahui tingkat efektifitas bahan ajar yang disusun terhadap peningkatkan pemahaman dan kemampuan aplikatif mahasiswa pada mata kuliah Metode Pembelajaran Bahasa dan Sastra Indonesia. Kegiatan tahun kedua ini merupakan tahap uji coba penggunaan bahan ajar untuk mengetahui prestasi dan respon mahasiswa, serta kendala yang dihadapi jika pembelajaran menggunakan bahan ajar yang disusun.
Bahan ajar yang telah tersusun memiliki peranan penting dalam pembelajaran. Dalam pandangan tradisional seperti dikemukakan oleh macomber (1952), bahan ajar merupakan "subject matter". Bahan ajar yang saat itu sering disebut materi pelajaran dikatakan sebagai suatu kebulatan pengetahuan yang tersusun secara sistematis dari satuan-satuan materi pelajaran. Pandangan modern justru menganggap materi pelajaran bukanlah tujuan. Bahan ajar adalah alat dan media yang memberi peluang kepada siswa untuk memperoleh pengalaman belajar. Dengan dan melalui bahan ajar yang tersedia, pembelajar akan memperoleh pengalaman berhubungan dengan a) fakta-fakta dalam kehidupan, b) model-model kehidupan, c) simbol-simbol yang dipakai dalam kehidupan (Sriasih, 2008). Melalui pengalaman ini pembelajar akan berlatih 1) menilai dan mengembangkan ide-ide, 2) memecahkan persoalan, 3) memperoleh keterampilan, dan 4) membina dan mengembangkan sikap mental serta daya apresiatif dan kreatif.

Bahan ajar yang tersusun dalam bentuk modul biasanya memberi peluang yang lebih banyak kepada mahasiswa untuk mencapai harapan di atas. Modul sendiri menurut Russel (1974:3) adalah "...an instructional package dealing with a single conseptual unit of subject matter", sedangkan Warwich (1996) mendefinisikan modul sebagai suatu unit kurikulum yang lengkap, dan dapat ditambah dengan pencapaian tugas yang lebih besar atau tujuan-tujuan jangka panjang. Modul sebagai bahan pembelajaran memiliki struktur yang khas terdiri dari pendahuluan yang berisi uraian singkat tentang cakupan materi modul, tujuan pembelajaran, dan urutan bahasan (kegiatan belajar). Pada Jurnal Pendidikan Indonesia | 104 
kegiatan belajar berisi sajian materi, contoh, latihan serta rangkuman yang bersifat interaktif untuk menumbuhkan pembelajaran (Winataputra, dkk, 1972:2). Modul diharapkan disusun sedemikian rupa agar memungkinkan 1) meningkatkan secara maksimal kegiatan pembelajaran, 2) terselenggaranya proses maju berkelanjutan secara efektif, 3) pembelajaran berpusat pada siswa (Depdikbud, 1985:4). Modul yang disusun dengan baik dapat memberikan banyak keuntungan, yaitu 1) dapat meningkatkan secara maksimal pembelajaran, 2) pembelajar lebih aktif dalam proses belajarnya karena menghadapi sejumlah masalah atau tugas yang harus dikerjakan, 3) dapat memberikan balikan dengan segera sehingga pembelajar dapat mengetahui hasil belajarnya, 4) kegiatan pembelajar terarah karena modul mengandung sasaran belajar yang jelas, dan 5) keterlibatan pengajar dalam pembelajaran sangat minimal (Russel, 1974:20; Suryobroto, 1983:16; dan Nasution, 2000:206).

\section{METODE PENELITIAN}

Penelitian ini menggunakan rancangan penelitian dan pengembangan dengan tahapan yang sering dikenal dengan 4-D (define, design, develop, disseminate). Pengembangan materi pembelajaran ini mengacu pada model pengembangan Dick \& Carey (1990).

Kegiatan penelitian ini terdiri dari: (1) melakukan analisis kebutuhan (need assesment), (2) menetapkan pokok-pokok materi yang akan dikembangkan, dan (3) mengembangkan prototype, (4) validasi ahli, (5) uji coba.

Pada tahun kedua dari pengembangan bahan ajar Metode PBSI ini dilakukan tahapan uji coba untuk mengetahui prestasi dan respon mahasiswa terhadap penggunaan bahan ajar yang tersusun. Selain itu, juga untuk mengetahui kendala yang dihadapi. Sehubungan dengan itu, data penelitian ini dikumpulkan dengan metode tes dan angket. Metode tes meliputi tes pemahaman dan tes unjuk kerja untuk menjaring kemampuan aplikatif. Angket dipakai untuk menjaring data respon dan kendala yang dihadapi. Untuk respon, digunakan angket terstruktur dan untuk kendala digunakan angket terbuka.

\section{HASIL DAN PEMBAHASAN \\ Hasil Prestasi mahasiswa}

Pelaksanaan uji coba penggunaan bahan ajar Metode PBSI dalam pembelajaran dilaksanakan pada semester genap tahun ajaran 2010/2011. Uji coba ini melibatkan tiga kelas yang ada di Jurusan Pendidikan Bahasa dan Sastra Indonesia dengan jumlah mahasiswa yang terlibat ketika uji coba sebanyak 60 orang dengan rincian sebagai berikut: kelas A sebanyak 28 orang, kelas $B$ sebanyak 18 orang, dan kelas C sebanyak 14 orang. Uji coba dilaksanakan sebanyak dua kali dengan materi yang diajarkan adalah pendekatan komunikatif dan model pembelajaran konstruktivisme.

Setelah dilakukan tes sehabis pelaksanaan pembelajaran dengan menggunakan bahan ajar "Metode PBSI" yang disusun ditemukan prestasi mahasiswa berada pada kategori baik dengan rata-rata 79,42 . Jika dilihat secara parsial masingmasing kemampuan, yaitu kemampuan pemahaman konsep dan kemampuan aplikatif, tampak ada perbedaan, walupun masih berada pada kategori baik. Rata-rata kemampuan pemahaman mahasiswa adalah 81,17 , sedangkan rata-rata kemampuan aplikatif adalah 76,8. 
Kemampuan pemahaman ternyata lebih tinggi dari kemampuan aplikatif dengan selisih 4,37 poin. Ini menunjukkan bahwa mahasiswa lebih mampu memahami konsep dibandingkan dengan mengaplikasikan konsep yang dipahaminya.
Jika dilihat perimbangan antara kategori prestasi mahasiswa, tampaknya sebagian besar mahasiswa tergolong ke dalam kategori sangat baik, seperti tampak pada tabel berikut.

Tabel 1: Perimbangan jumlah dan persentase kategori prestasi mahasiswa

\begin{tabular}{|l|l|l|l|}
\hline No & Kateori & Jumlah & Persentase \\
\hline 1. & Sangat baik & 27 & 45 \\
\hline 2. & Baik & 21 & 35 \\
\hline 3. & Cukup & 12 & 20 \\
\hline 4. & Kurang & - & - \\
\hline 5. & Sangat kurang & - & - \\
\hline \multicolumn{2}{|c|}{ Jumlah } & 60 & 100 \\
\hline
\end{tabular}

Tabel di atas memperlihatkan perimbangan tingkat prestasi mahasiswa berdasarkan kategorinya. Dari tabel tersebut terlihat bahwa kategori prestasi mahasiswa berada pada tiga kategori yaitu sangat baik, baik, dan cukup. Tidak ada mahasiswa yang berada pada kategori kurang dan sangat kurang. Kategori sangat baik bahkan menduduki peringkat teratas dengan jumlah $45 \%$. Kategori cukup malahan berada pada peringkat paling rendah dengan jumlah $20 \%$ masih di bawah kategori baik yang sebesar $35 \%$.

\section{Hasil Respon Mahasiswa}

Utuk menjaring respon mahasiswa terhadap efektivitas penggunaan bahan ajar Metode PBSI dalam pembelajaran, digunakan delapan pernyataan. Kedelapan pernyataan tersebut adalah (1) Saya senang dengan pembelajaran dengan cara seperti yang diterapkan dosen, (2) Saya senang dosen memberikan bahan ajar untuk didiskusikan, (3) Saya tertarik dengan model penataan bahan ajar yang diberikan, (4) Saya dapat memahami bahan ajar yang diberikan guru, (5) Bahan ajar memudahkan saya dalam memahami materi pelajaran, (6) Saya bisa mengaplikasikan konsep yang ada pada bahan ajar untuk menyusun skenario pembelajaran, (7) Saya bisa membuat skenario pembelajaran dengan mengkaji bahan ajar yang diberikan dosen secara berkelompok, dan (8) Saya ingin dosen tetap memberikan bahan ajar dalam setiap pembelajaran. Hasil angket berupa respon mahasiswa terhadap penggunaan bahan ajar Metode PBSI dalam pembelajaran, dapat dilihat pada tabel berikut. 
Tabel 2: Hasil angket respon mahasiswa terhadap penggunaan bahan ajar metode PBSI dalam pembelajaran

\begin{tabular}{|c|c|c|c|c|c|c|c|}
\hline \multirow{2}{*}{$\begin{array}{c}\text { No. } \\
\text { Pernyataan }\end{array}$} & \multicolumn{5}{|c|}{ Pilihan Jawaban } & \multirow[b]{2}{*}{ Rerata } & \multirow[b]{2}{*}{ Kategori } \\
\hline & $\begin{array}{l}\text { SS } \\
\text { (5) }\end{array}$ & $\begin{array}{c}S \\
\text { (4) }\end{array}$ & KS (3) & $\begin{array}{l}\text { TS } \\
\text { (2) }\end{array}$ & $\begin{array}{c}\text { STS } \\
\text { (1) }\end{array}$ & & \\
\hline 1. & 45 & 15 & - & - & - & 4,75 & Sangat positif \\
\hline 2. & 35 & 25 & - & - & - & 4,58 & Sangat positif \\
\hline 3. & 25 & 35 & - & - & - & 4,42 & positif \\
\hline 4. & 5 & 55 & - & - & - & 4,01 & positif \\
\hline 5. & 20 & 40 & - & - & - & 4,33 & Positif \\
\hline 6. & 20 & 40 & - & - & - & 4,33 & positif \\
\hline 7. & 20 & 40 & - & - & - & 4,33 & Positif \\
\hline 8. & 45 & 15 & - & - & - & 4,75 & Sangat positif \\
\hline Jumlah rata & +3 & +6 & & & & 4,43 & Positif \\
\hline
\end{tabular}

Berdasakan tabel hasil angket di atas, terlihat bahwa mahasiswa merespon positif penggunaan bahan ajar Metode PBSI dalam pelaksanaan pembelajaran dengan rata-rata respon adalah 4,43 dalam kategori positif. Dari delapan item pernyataan pada angket, semua pernyataan dijawab positif oleh mahasiswa. Hal ini lebih memperkuat ratarata semua item yang sebasar 4,43 tersebut.

\section{Kendala yang Dihadapi dalam Pembelajaran}

Dari angket bebas yang diisi oleh mahasiswa mengenai kendala dalam pelaksanaan pembelajaran ditemukan adanya dua kendala dalam pemanfaat bahan ajar Metode PBSI. Kedua kendala tersebut adalah (1) waktu yang terbatas dan (2) ada beberapa bagian materi yang sulit dipahami (berupa kutipan asli). Semua mahasiswa menyatakan kendala waktu sebagai kendala utama. Mengenai kendala kedua, hanya ditemukan sebanyak 50\%. Artinya hanya $50 \%$ mahasiswa sampel yang menyatakan ada beberapa bagian dari bahan ajar yang sulit dipahami. Setelah ditelusuri, ternyata kesulitan terletak pada kutipan asli yang tidak diadaptasi sesuai konteks wacana pada bahan ajar tersebut dan juga kesesuaian dengan pola bahasa atau ragam bahasa yang dikendaki oleh mahasiswa.

\section{PEMBAHASAN}

Dari temuan yang telah dikemukakan di depan, maka ada beberapa temuan menarik yang perlu dibahas lebih lanjut. Pembahasan ini meliputi prestasi mahasiswa, respon, dan kendala yang dihadapi ketika pelaksanaan pembelajaran dengan menggunakan bahan ajar yang telah disusun.

Prestasi mahasiswa yang rata-rata umumnya adalah 79,42 dengan kategori baik, tampaknya merupakan sinya bahwa pembelajaran dengan menggunakan bahan ajar yang telah disusun tampaknya mempunyai pengaruh yang cukup signifikan. Apalagi rata-rata umum ini adalah gabungan nilai pemahaman dan aplikatif yang untuk pertama kalinya dilakukan penilaian secara berimbang. Maksud berimbang di sini 
adalah penilaian aplikatif yang selama ini jarang dilakukan dalam perkuliahan mata kuliah Metode Pembelajaran, umumnya, dan khususnya Metode PBSI, sekarang ini dilakukan secara lebih seksama yang menjadi bagian yang setara dengan pemahaman konsep.

Pemberian bahan ajar yang tercetak kepada mahasiswa tampaknya juga ikut berkontribusi terhadap prestasi mereka mengikuti perkuliahan. Logikanya adalah dengan diberikan bahan ajar yang tercetak, maka waktu yang biasanya tersita untuk mencatat materi dapat dikurangi dan konsentrasi mahasiswa untuk bekerja dalam pembelajaran dapat ditingkatkan. Hal ini tampaknya disebabkan oleh komponen bahan ajar seperti kompetensi dasar dan indikator yang secara eksplisit dapat mereka baca dari bahan ajar ini. Sesuai dengan konsep pembalajaran seperti dikemukakan dalam konsep pembelajaran mikro, bahwa pemahaman dan konsentrasi mahasiswa dapat ditingkatkan jika mereka mengetahui dari awal tujuan pemnbelajarannya dan langkah-langkah kegiatan yang dapat dilakukan selama pembelajaran.

Hal menarik yang berkaitan dengan prestasi yang juga perlu dicermati adalah adanya perbedaan kemampuan pemahaman dan kemampuan aplikatif. Kemampuan pemahaman lebih tinggi perolehan hasilnya yaitu sebesar 81,17, sedangkan kemampuan aplikatif sebesar 76,8 . Ada selisih 4,37 poin dari kedua kemampuan tersebut. Hal ini dapat dijelaskan bahwa kemampuan aplikatif memang merupakan tingkatan yang lebih tinggi jika melihat taksonomi Bloom. Karena tingkatannya lebih tinggi yaitu tergolong C3 sedang pemahaman C2, maka wajarlah kemampuan aplikatif lebih sulit sehingga prestasinya lebih rendah dibandingkan pemahaman. Akan aneh, jika nilai pemahaman lebih rendah dibandingkan aplikatif. Walaupun demikian, prestasi ini masih dapat ditingkatkan jika kendala yang dihadapi selama pembelajaran dapat dihilangkan.

Ada dua kendala yang dikemukakan oleh mahasiswa dalam penerapan bahan ajar ini. Kendala pertama adalah kurangnya waktu pembelajaran. Kendala kedua adalah ada beberapa bagian materi yang sulit dipahami oleh mahasiswa. dalam hal kendala waktu, mahasiswa menganggap waktu yang tersedia untuk mengerjakan tugas perkuliahan yang menyangkut pemahaman dan kemampuan aplikatif masih terlalu singkat. Hal ini juga peneliti rasakan. Kekurangan waktu ini terjadi bisa karena beberapa kemungkinan. Jika dilihat dari konsep pembelajaran, mahasiswa atau siswa yang tidak ingat dengan berjalannya waktu selama pembelajaran adalah mahasiswa atau siswa yang asyik mengerjakan tugas-tugas pembelajaran. Kemungkinan yang lain adalah tugas yang terlalu banyak sehingga terasa waktu tersedia sedikit atau memang waktunya sedikit. Kedua kemungkinan ini tampaknya ada pada penelitian ini. Mahasiswa memang tampak asyik bekerja sehingga mereka lupa waktu. Di lain pihak, waktu perkuliahan untuk mata kuliah Metode PBSI memang kurang karena terjadi perubahan berupa pengurangan jumlah JS dari 4 JS untuk 2 SKS menjadi 2 JS untuk 2 SKS. Peneliti mengamati waktu pembelajaran yang hanya 2 JS tampaknya tidak mencukupi untuk pencapaian tingkat pemahaman dan kemampuan aplikatif dalam perkuliahan Metode PBSI.

Walaupun ada kendala seperti di atas, mahasiswa merespon positif $(4,43)$ penggunaan bahan ajar yang disusun untuk Jurnal Pendidikan Indonesia | 108 
digunakan dalam pembelajaran. Dari delapan item yang diajukan yang diajukan tidak ada yang direspon tidak positif. Mahasiswa merespon sangat positif dosennya mengajar dengan model pembelajaran yang menggunakan bahan ajar, bahkan mereka sangat menginginkan dosen terus mengajar dengan memberikan bahan ajar seperti pada saat penelitian. Selain itu, bahan ajar yang diberikan memudahkan mereka mempelajari materi sehingga dengan bahan ajar itu mereka merasa mampu membuuat skenario pembelajaran yang inovatif. Yang paling kecil responnya adalah tingkat keterbacaan bahan ajar yang memudahkan mereka memahami materi. Tampak ini menjadi salah satu kendala juga dalam pembelajaran dengan bahan ajar ini. Mahasiswa menyatakan ada beberapa bagian materi yang sulit dipahami. Setelah ditelusuri, ternyata bagian yang sulit itu adalah bagian-bagian yang kebanyakan berupa kutipan langsung dari buku lain. Kesulitan memahami kutipan langsung ini tampaknya disebabkan oleh gaya tulisan atau ragam bahasa yang digunakan oleh penulis. Ragam tulisan tersebut untuk ukuran mahasiswa sampel masih sulit dicerna. Kendala ini dipecahkan dengan jalan mengurangi kutipan langsung agar gaya atau ragam bahasanya linier dengan gaya atau ragam bahasa pada bagianbagian lainya dari bahan ajar ini.

\section{SIMPULAN DAN SARAN Simpulan}

Bersadarkan hasil analisis data dan pembahasan terhadap hasil penelitian, maka dapat disimpulkan sebagai berikut.

1. Prestasi mahasiswa setelah diajarkan dengan menggunakan bahan ajar "Metode Pembelajaran Bahasa dan
Sastra Indonesia" yang telah disusun berada pada kategori baik dengan ratarata nilai 79,42 untuk gabungan kedua kemampuan (kemampuan pemahaman dan kemampuan aplikatif). Secara sendiri-sendiri, terlihat ada perbedaan kemampuan pemahaman (rata-rata $81,17)$ dengan kemampuan aplikatif (rata-rata 76,8). Perbedaan hasil ini menunjukkan bahwa mahasiswa lebih sulit mengaplikasikan konsep dibandingkan dengan sekadar memahami konsep.

2. Respon mahasiswa terhadap penggunaan bahan ajar "Metode Pembelajaran Bahasa dan Sastra Indonesia" yang telah disusun tergolong ke dalam kategori positif dengan ratarata skor 4,43. Artinya bahan ajar yang disusun dianggap cukup berkontribusi dalam usaha mahasiswa memahami dan mengaplikasikan konsep mata kuliah Metode PBSI.

3. Ada dua kendala yang dihadapi oleh mahasiswa dalam pembelajaran dengan menggunakan bahan ajar Metode PBSI yang telah disusun. Kendala tersebut adalah (1) kekurangan waktu untuk mengerjakan tugas-tugas dan (2) ada beberapa bagian materi yang sulit dipahami sehingga penjelasan maupun bimbingan dosen pengajar masih diperlukan.

4. Uji coba penggunaan bahan ajar ini dalam pembelajaran mengisyaratkan bahwa bahan ajar yang telah disusun cukup efektif sebagai sarana untuk mengajarkan mata kuliah Metode Pembelajaran Bahasa dan Sastra Indonesia. Tingkat efektivitas tersebut tampak dari prestasi yang ditunjukkan oleh mahasiswa setelah mereka diajarkan dengan bahan ajar yang Jurnal Pendidikan Indonesia | 109 
disusun. Selain itu, respon positif mahasiswa juga menunjukkan bahwa bahan ajar ini efektif sebagai sarana belajar.

\section{Saran-saran}

Berdasarkan simpulan terhadap temuan pada penelitian ini, maka beberapa saran dapat diajukan.

1. Pengembangan bahan ajar yang disusun dengan prinsip yang sistematis ternyata dapat menunjang peningkatan prestasi mahasiswa seperti pada temuan ini. Berdasarkan kenyataan itu dapat disarankan kepada pihak yang berkeinginan menyusun bahan ajar hendaknya mengikuti model pengembangan bahan ajar yang sistemetis dengan tahapan yang jelas.

2. Respon positif mahasiswa terhadap penggunaan bahan ajar dalam perkuliahan mengindikasikan bahwa sangat penting kiranya menyiapkan bahan ajar sebagai sarana perkuliahan. Bahan ajar akan menggugah mahasiswa untuk asyik bekerja karena mereka memiliki pegangan yang pasti mengenai tugasnya pada pertemuan tersebut.

3. Walaupun model pengembangan bahan ajar ini dikhususkan penggunaannya untuk Jurusan Pendididkan Bahasa dan Sastra Indonesia di Undiksha, namun kepada pihak yang memerlukan prosedur pengembangan bahan ajar tampaknya model pengembangan ini dapat memberikan inspirasi untuk dicobakan pada jenis bahan ajar lainnya yang sejalan.

\section{DAFTAR RUJUKAN}

Arends, R. I., Wenitzky, N. E., \& Tannenboum, M. D. 2001. Exploring teaching: An introduction to education. New York: McGraw-Hill Companies.

Dahar, R. W. 1989. Teori-teori belajar. Jakarta: Erlangga.

Depdikbud.1985. Pedoman Penyusunan Modul. Jakarta. Badan Pengembangan PendidikanDepdikbud.

Dick, W. \& I. Carey. 1990. The Systematic Design of Instructional. USA: Harper Collin.

Gunter, M. A., Estes, T. H., \& Schwab, J. H. 1990. Instruction: A models approach. Boston: Allyn and Bacon.

Jacobs, G.M., Lee, G.S, \& Ball, J. 1996. Learning Cooperative Learning via Cooperative Learning: A Sourcebook of Lesson Plans for Teacher Education on Cooperative Learning. Singapore: SEAMEO Regional Language Center.

Jigsaw. 2011. http://www.jigsaw.org/

Johnson, Keith \& Morrow, Keith. 1987. Communication in the Classroom: Aplications and Methods for a Communicative Approach. England: Longman Group Ltd.

Joyce, B., \& Weil, M. 1980. Model of teaching. New Jersey: Prentice-Hall, Inc.

Kessler, Carolyn. 1992. Cooperating Language Learning: A Teacher's Resource Book. Englewood Cliffs, N.J.: Prentice Hall Regents.

Lie Anita, 2005. Coopertive Learning( mempraktikkan cooperative learning di ruang-ruang kelas). Jakarta: Grasindo.

Marton, Waldemar. 1988. Methods in English Teaching: Framework and Options. New York: Prentice Hall.

Muslimin,M.pd,dkk. $2000 . \quad$ Model Pembelajaran Kooperatif. Surabaya: Universitas Negeri Surabaya.

Nasuitin, S. 2000. Berbagai Pendekatan dalam Proses Belajar dan Mengajar. Jakarta: Bumi Aksara.

Jurnal Pendidikan Indonesia | 110 
Nunan, David. 1991. Language Teaching Methodelogy: A Texbook for Teachers. New York: Printice Hall.

Nurjaya, Gede. 2009. Penggunaan Model Pembelajaraan Kooperatif Jigsaw pada Pembelajaran Metode Pembelajaran Bahasa dan Sastra Indonesia untuk Meningkatkan Pemahaman dan Kemampuan Aplikatif Mahasiswa. Laporan Penelitian (tidak diterbitkan). Undiksha: Singajara

Nurjaya, Gede. 2010. Pengembangan Bahan Ajar Metode Pembelajaran Bahasa dan Sastra Indonesia Berbasis Pembelajaran Kooperatif Jigsaw untuk Meningkatkan Pemahaman dan Kemampuan Aplikatif Mahasiswa. Laporan Penelitian (tidak diterbitkan). Undiksha: Singaraja

Russel, J.D. 1974. Modular Instructional. A Guide to the Design, Selection, Utilization and Evaluation of Modular Materials. Minneapolish, Minnesota: Burgess.

Slavin, R. E. 1995. Cooperative learning. Second edition. Boston: Allyn and Bacon.

Sriasih, S.A.P. 2008. Telaah Buku Teks. Singaraja: Undiksha.

Suandi, Nengah, dkk. 2010. Pengembangan Materi Pembelajaran Mata Kuliah Aplikasi Bahasa Indonesia di Perguruan Tinggi Berorientasi Integrasi Nasional dan Harmoni Sosial. Laporan Penelitian (Tidak diterbitkan). Undiksha: Singaraja.

Suryosuroto, B. 1983. Sistem Pengajaran dengan Modul. Yogyakarta: Bina Aksara.

Winataputra, dkk. 1977. Panduan Operasional Penulisan Modul. Jakarta: Depdikbud-UT FKIP. 